\title{
Sensitivity of the Arctic freshwater content and transport to model resolution
}

\author{
Ramón Fuentes-Franco ${ }^{1,2} \cdot$ Torben Koenigk $^{1,2}$
}

Received: 18 April 2018 / Accepted: 16 March 2019 / Published online: 25 March 2019

(c) The Author(s) 2019

\begin{abstract}
We compare the representation of the Arctic liquid and solid freshwater volumes, and their transports to/from the Arctic, using simulations with different ocean and atmosphere model resolutions from models participating in the EU H2020 PRIMAVERA project. Regarding ocean resolution, we find less liquid freshwater in the central Arctic Ocean and more in the Kara and Laptev seas in the model simulations at higher resolution compared with the model simulations at lower resolution. The mean sea ice thickness does not show a systematic behaviour across models regarding model resolution increase. In terms of atmospheric resolution, we find that both liquid freshwater and mean sea ice thickness decrease when the resolution of the atmospheric model increases. We also analyze differences of Arctic liquid freshwater volume and mean sea ice thickness caused by pre-industrial and historical atmospheric forcings. Pre-industrial simulations show less freshwater volume and increased mean sea ice thickness and export from the Arctic compared with present day simulations. Finally, we find an increasing impact of Arctic freshwater export on North Atlantic convection with increased atmospheric resolution.
\end{abstract}

\section{Introduction}

Freshwater in the Arctic Ocean plays an important role in the global climate system. Cold liquid freshwater forms a thin surface layer in the Arctic Ocean that separates the warmer water below from the sea ice and the atmosphere. It limits the upward transfer of heat and thus influences the formation and melting of sea ice. The export of freshwater is important for the coupling of the Arctic Ocean to the global oceanic circulation system. Arctic freshwater exports affect the deep oceanic convection in the North Atlantic (Haak et al. 2003; Koenigk et al. 2007). The most prominent example is the so called Great Salinity Anomaly in the Labrador Sea (Dickson et al. 1988; Häkkinen 1999; Koenigk et al. 2006). Deep convection in the Labrador Sea is the largest source for the thermohaline part of the Atlantic Meridional Overturning Circulation (AMOC; Brodeau and Koenigk 2016; Koenigk and Brodeau 2017; Rennermalm et al. 2007). Jungclaus et al. (2005) and Holland et al. (2001) showed the importance

Ramón Fuentes-Franco

ramon.fuentesfranco@smhi.se

1 Rossby Centre, Swedish Meteorological and Hydrological Institute, Norrköping, Sweden

2 Bolin Centre for Climate Research, Stockholm University, Stockholm, Sweden of Arctic freshwater export variations for the variability of the AMOC. Freshwater impacts also the horizontal gyres (Brauch and Gerdes 2005), which have an impact on biological processes, both within the Arctic itself, and at lower latitudes (Haine et al. 2015).

Freshwater is supplied to the Arctic by three principal mechanisms: runoff, precipitation minus evaporation $(\mathrm{P}-\mathrm{E})$ and oceanic inflow, including ice melting (Haine et al. 2015). The most important freshwater source is the river runoff (Peterson et al. 2002; Berezovskaya et al. 2005; Déry and Wood 2005; McClelland et al. 2006). Runoff from rivers, streams, and groundwater discharge supplies around $0.124 \mathrm{mSv} \pm 0.0124 \mathrm{mSv}$ or $3900 \pm 390 \mathrm{~km}^{3} \mathrm{year}^{-1}$ to the Arctic Ocean. The net effect of precipitation and evaporation delivers another $2000 \pm 200 \mathrm{~km}^{3}$ year ${ }^{-1}$ into the Arctic (Haine et al. 2015).

The largest export of liquid freshwater from the Arctic into the North Atlantic occurs via the Canadian Arctic Archipelago and Baffin Bay with around $3200 \pm 320 \mathrm{~km}^{3} \mathrm{year}^{-1}$ at Davis Strait (Serreze et al. 2006). Export of liquid freshwater through Fram Strait is also important and reaches around $2700 \pm 530 \mathrm{~km}^{3}$ year $^{-1}$ (Serreze et al. 2006). The freshwater flux through the Barents Sea Opening is relatively small with an outflow from the Arctic of around $90 \pm 90 \mathrm{~km}^{3}$ year $^{-1}$, based on a reference salinity $\left(\mathrm{S}_{\text {ref }}\right)$ of $34.80 \mathrm{psu}$. In turn, the largest inflow occurs through the Bering Strait supplying 
around $2400 \pm 300 \mathrm{~km}^{3}$ year $^{-1}$ (Woodgate et al. 2006; Serreze et al. 2006).

One of the main currents through which ice is exported out of the Arctic Ocean is the Transpolar Drift Stream which transports sea ice from the Siberian sector of the Arctic Basin across the North Pole towards the Fram Strait and further into the Greenland Sea. The largest source of sea ice export is across the Fram Strait and amounts from 2400 up to $3200 \mathrm{~km}^{3}$ year $^{-1}$ (Vinje et al. 1998; Vinje 2001; Aagaard and Carmack 1989; Schmith and Hansen 2003). This amount of freshwater export as ice, is comparable with the liquid freshwater export; however ice export is much more dependent on atmospheric dynamics, due to its confinement to the sea surface. It has been shown that the interannual variability of ice export across the Fram Strait is mainly dominated by the sea level pressure gradient across Fram Strait. According to several studies (Kwok and Rothrock 1999; Vinje 2001; Hilmer et al. 1998; Koenigk et al. 2006), this pressure gradient explains more than $80 \%$ of the total variability of the ice export.

Recent studies addressing model uncertainty of Arctic freshwater have found that models show a pronounced spread regarding liquid freshwater transport amounts from the Arctic across gateways and straits. According to Jahn et al. (2012) the highest inter-model agreement is found for the interannual and seasonal variability of the solid freshwater export and the solid freshwater storage, which also agree well with observations. In particular, Wang et al. (2017) suggested that the spread on the freshwater export from the Arctic towards the Atlantic might be a result of the different representations of the straits (width, depth and grid spacing) and numerical schemes (e.g., momentum advection and boundary conditions). Although Wang et al. (2017) did not attribute a one way response to model resolution, they found that increased horizontal ocean model resolution does not necessarily lead to liquid freshwater fluxes comparable with observations. Ilicak et al. (2016) found in a CMIP5 inter-comparison analysis that the freshwater export might be linked to the proper representation of the subduction, since in the majority of models, water from the Arctic subducts just before or at the Fram Strait. Ilicak et al. (2016) mentioned that an accurate modelling of the subduction processes would likely require higher resolution models with a realistic representation of the varying thickness of the seasonal mixed layer depth, eddy mixing along local neutral surfaces, eddy restratification of density fronts and eddy-topography interactions.

In order to address the impact of ocean and atmosphere model resolutions on representing different oceanic and atmospheric processes, the EU H2020 PRIMAVERA project collected the latest existing high resolution global model simulations (performed between CMIP5 and CMIP6) from several European modelling groups. The analysis of these model simulations (pre-PRIMAVERA simulations) is a first step of the PRIMAVERA project before performing and analyzing high-resolution simulation following the High Resolution Model Intercomparison Project (HighResMIP) for CMIP6 (Haarsma et al. 2016).

By keeping the same physical parameterization across resolutions within each model, we assess the impact of increased ocean and atmospheric model resolutions on the Arctic freshwater content and transport. Similarly, we analyse the impact of present-day simulations (using current greenhouse gas concentrations) on Arctic freshwater content and transport, compared to preindustrial levels. Furthermore, we assess the impact of the freshwater budget on the oceanic convection in the North Atlantic.

Thus, this article intends to provide the state of knowledge of the resolution dependency of the Arctic freshwater content and its export across different straits.

\section{Data and methods}

\subsection{Model description}

We used three different coupled global climate models (GCMs): EC-Earth3.1, HadGEM3-GC2 and CMCC-CM2. Details of the coupled GCMs are listed in Table 1.

The EC-Earth3.1 model (Hazeleger et al. 2010, 2012; Sterl et al. 2012) is composed by the Integrated Forecast System (IFS) as the atmospheric component and the Nucleus for European Modelling of the Ocean (NEMO) as ocean component (Madec 2008) coupled with the Louvain la Neuve sea ice model version 3 (LIM3, Vancoppenolle et al. 2012). NEMO uses tripolar grid configurations called ORCA. Two simulations from EC-Earth3.1 are analyzed in this paper: a 60-year low resolution simulation (T255 atmosphere resolution with reduced Gaussian grid in IFS corresponding to $\sim 80 \mathrm{~km}$ and ORCA1 for the ocean) and a 25 -year high resolution simulation (T511 atmosphere resolution corresponding to $\sim 40 \mathrm{~km}$ and ORCA025 ocean resolution), both of them using historical forcing. The ORCA1 configuration corresponds to a horizontal resolution of around $1^{\circ}$ in the extra-tropics and has a refined meridional resolution in the tropics with a minimum value of $0.3^{\circ}$ at the Equator. It has 46 vertical levels, 18 of which are in the upper $200 \mathrm{~m}$, the first level having $10 \mathrm{~m}$ thickness. ORCA025 configuration has a horizontal resolution of around $0.25^{\circ}$ with 75 vertical levels.

The HadGEM3-GC2 (Williams et al. 2015) configuration consists of the following models components: GlobalAtmosphere v6.0, Global-Land v6.0, Global-Ocean v5.0 and Global Sea-Ice v6.0. The Unified Model atmospheric model is coupled to NEMO. Three atmospheric resolutions (N96: $136 \mathrm{~km}, \mathrm{~N} 216: 61 \mathrm{~km}$, and N512: $25 \mathrm{~km}$ ) are used 
Table 1 Name of models, resolutions, number of years and forcings of the simulations used in this study

\begin{tabular}{lllll}
\hline Model & $\begin{array}{l}\text { Atmosphere horizontal } \\
\text { resolution }\end{array}$ & $\begin{array}{l}\text { Ocean horizontal } \\
\text { resolution }\end{array}$ & Number of years (period) & Forcing \\
\hline EC-EARTH3.1 & T255 $(80 \mathrm{~km})$ & ORCA1 & $60(1950-2009)$ & Historical \\
EC-EARTH3.1-HR & T511 $(39 \mathrm{~km})$ & ORCA025 & $25(1990-2014)$ & Historical \\
CMCC-CM2 & $0.93^{\circ} \times 1.25^{\circ}$ & ORCA1 & 300 & Present day conditions (PD) \\
CMCC-CM2 & $0.93^{\circ} \times 1.25^{\circ}$ & ORCA1 & 40 & Pre-industrial (PI) \\
CMCC-CM2 & $0.93^{\circ} \times 1.25^{\circ}$ & ORCA025 & 40 & Present day conditions (PD) \\
CMCC-CM2 & $0.93^{\circ} \times 1.25^{\circ}$ & ORCA025 & 40 & Pre-industrial (PI) \\
HadGEM3-GC2 & N96 $(135 \mathrm{~km})$ & ORCA025 & 100 & Present day conditions (PD) \\
HadGEM3-GC2 & $\mathrm{N} 216(40 \mathrm{~km})$ & ORCA025 & 100 & Present day conditions (PD) \\
HadGEM3-GC2 & $\mathrm{N} 512(25 \mathrm{~km})$ & ORCA025 & 100 & Present day conditions (PD) \\
\hline
\end{tabular}

and coupled to a ORCA025 ocean grid (eddy-permitting). For each of the three model setups, 100 year-simulations with present-day (year 2000) external forcings as greenhouse gases and aerosols were performed.

The CMCC-CM2 model used in this study is a fullycoupled, global climate model, largely based on the Community Earth System Model (CESM), but having a different oceanic component. It represents the physical core of the new CMCC Earth system model (Fogli and Iovino 2014). The system is composed by the Community Atmosphere Model (CAM5; Hurrell et al. 2013) using the finite-volume dynamical core as atmospheric component coupled to the Community Land Model (CLM4.0; Lawrence et al. 2011). The ocean component is based on the NEMO framework (version 3.4; Madec et al. 2012), coupled with the Community Ice Code, version 4 (CICE4; Hunke and Lipscomb 2008) as the ice model. The component models are connected and synchronized by the CESM coupler/driver (cpl7) (Craig et al. 2012), which is also responsible for the exchange of energy, mass, and momentum fluxes between the different components. Two model configurations with $\sim 1^{\circ}$ atmospheric resolution coupled to two different ocean meshes, i.e. ORCA1 and ORCA025, are used to perform the CMCC-CM2 simulations (Table 1). Each configuration is run over both the pre-industrial (PI) and the present-day (PD) periods. PI and PD simulations use constant greenhouse concentration corresponding to observations from the year 1850 and 2000, respectively.

All models differ in length and external forcing. Further, the increase in resolution between the low resolution version and the high resolution version is not consistent across the models. This might make comparison between different models complicated. We will thus mainly focus on the effect of resolution in those pairs of simulations that are really comparable to each other. The CMCC-CM2 simulations allow to investigate the impact of increased ocean resolution and the impact of pre-industrial versus present day forcing. In the HadGEM simulations, we can analyze the effect of increasing only the atmospheric resolution. The two EC-Earth3.1 simulations provide information about the combined effect of increased resolution in ocean and atmosphere. The increase in ocean resolution is similar in EC-Earth and CMCC, i.e. the coarse resolution is $1^{\circ}$ and the high resolution is $0.25^{\circ}$, which also allows us to compare effects of resolution in oceanic processes from different models.

\subsection{Reanalyses}

The model results are compared to reanalysis products and observations. For sea ice concentration and sea ice transport, we used the Mercator Océan GLobal Ocean ReanalYsis and Simulations (GLORYS) reanalysis (Ferry et al. 2010) version 2.1 .

This global ocean/ice eddy-permitting GLORYS2V1 reanalysis uses the ORCA025-L75 configuration of the NEMO3.1 Ocean General Circulation Model (OPA ocean), with $0.25^{\circ}$ horizontal resolution and 75 vertical levels refined near the surface, with 1-m to 100 -m layer thickness from surface to bottom (Barnier et al. 2009). It is forced with 3-hourly ECMWF ERA-Interim atmospheric field using CORE bulk formulae (Large and Yeager 2004). The simulation is initialised in December 1991 with WOA98 ocean and NSDIC sea-ice climatologies. The sea-ice component is the LIM2 sea-ice model (Goosse and Fichefet 1999). GLORYS2V1 uses the SAM2 (Système d'Assimilation Mercator V2) data assimilation system, a reduced order extended Kalman filter with the capability to manage a various and high number of observations and which is specially designed for expensive configurations. This reanalysis starts in 1993 when satellite altimetry measurements of sea level provide reliable information on ocean eddies. This reanalysis which covers the 1993-2009 period, benefits from the Argo float measurements and its validation results suggest that GLORYS2V1 reanalysis has a good skill in estimating and reproducing the observed variability of the main oceanic 
variables (Ferry et al. 2012). We also use the GLORYS2V4 reanalysis, an updated version of GLORYS2V1, which also uses the NEMOv3.1 ocean model with the same vertical and horizontal resolution. The data assimilation technique is a multi-data and multivariate reduced order Kalman filter based on the Singular Extended Evolutive Kalman (SEEK) filter formulation. A bias correction scheme for temperature and salinity is also included. The assimilated observations are time delayed along track satellite Sea Level Anomaly, Sea Ice Concentration, Sea Surface Temperature, and in situ profiles of temperature and salinity from CORA4 data base. GLORYS2V4 includes the 1993-2015 period.

For freshwater transport we used the ECMWF Ocean ReAnalysis system (ORAS4, Balmaseda et al. 2013), which uses NEMO as the ocean component, and the variational assimilation system NEMOVAR (Mogensen et al. 2012). It uses ERA-Interim forcing fluxes, revised quality-controlled datasets with corrections to the eXpendable BathyThermographs (XBTs), Argo data for the estimation of model bias, and a revised ensemble generation strategy that should sample better the uncertainty in the deeper ocean compared to previous versions. ORAS4 has approximately $1^{\circ}$ resolution in the extratropics and refined meridional resolution in the tropics with a minimum value of $0.3^{\circ}$ directly at the equator. Of the 42 vertical levels, 18 are in the upper $200 \mathrm{~m}$. The first level has a $10 \mathrm{~m}$ thickness. ORAS4 includes the 1958-2012 period.

For comparison reasons, for freshwater transport we also used the Ocean ReAnalysis Pilot 5 (ORAP5, Zuo et al. 2015) produced with the NEMO3.4.1 ocean model (Madec 2008) on a ORCA025 grid (horizontal resolution of $0.25^{\circ}$ and 75 levels in the vertical), with variable vertical spacing (the top level has $1 \mathrm{~m}$ thickness). ORAP5 includes the LIM2 sea ice model. As for ORAS4, ORAP5 surface forcing comes from ERA-Interim, and includes the impact of surface waves in the exchange of momentum and turbulent kinetic energy. The reanalysis is conducted with NEMOVAR (Mogensen et al. 2012) in its 3D-Var FGAT (the first-guess at appropriate time) configuration. The assimilation of subsurface temperature, salinity, sea-ice concentration (SIC) and sea level anomalies, is performed using NEMOVAR. In addition, sea surface temperature (SST), sea surface salinity (SSS), and global mean sea level trends are used to modify the surface fuxes of heat and freshwater.

\subsection{Freshwater content calculation}

We calculated the freshwater content (FWC) in the Arctic following Aagaard and Carmack (1989), Serreze et al. (2006) and Haine et al. (2015). FWC is quantified by the amount of zero-salinity water required to reach the observed salinity of a seawater sample starting from a particular reference salinity. Specifically, liquid FWC (in meters) is estimated as

$F W C=\int_{D}^{\eta} \frac{S_{r e f}-S}{S_{r e f}} d z$

for salinity $\mathrm{S}$ (in practical salinity units). Reference salinity $\mathrm{S}_{\text {ref }}$ was considered as $34.80 \mathrm{psu}$. The integration along $\mathrm{z}$ is performed from the bottom at depth $\mathrm{D}$ to the sea surface at height $\eta$.

\section{Results and discussion}

\subsection{Freshwater content and mean sea-ice thickness}

In the reanalyses ORAS4 and ORAP5 we found that much of the Arctic Ocean's freshwater is stored in the Beaufort Gyre (Fig. 1a, b). According to Serreze et al. (2006), this is a response to the mean Beaufort Sea atmospheric anticyclone that promotes Ekman convergence. Saltier water (Atlantic waters entering the Arctic Ocean) extends from the Norwegian Sea along the eastern side of the Fram Strait northwards into the Nansen and Amundsen Basins until the Laptev Sea. Along the shelves of the Siberian coast and in the Canadian Archipelago, the water is fresh due to the incoming river runoffs. EC-Earth3.1 at low resolution shows saltier conditions in the entire Arctic compared to ORAS4 and ORAP5 (Fig. 1c). The high resolution version of ECEarth3.1 (Fig. 1d) show saltier Arctic than the coarse resolution, which appears to be the model with lower FWC.

The four CMCC-CM2 simulations show a FWC pattern similar to the reanalyses, the high resolution ORCA025 showing a saltier Beaufort Sea (Fig. 1f, h) than the ORCA1 ocean resolution simulations (Fig. 1e, g). Both CMCC PI simulations (Fig. 1e, f) show saltier conditions over the Central Arctic and the Beaufort Sea compared with CMCC PD simulations (Fig. 1g, h).

The three HadGEM3-GC2 simulations show a similar pattern to ORAS4 and ORAP5 with higher freshwater content compared to the reanalyses. With higher atmospheric resolution (Fig. 1i-k), the FWC agrees better with reanalyses over the Nansen Basin and the Laptev Sea, however the simulations show higher FWC over the Beaufort Sea than the reanalyses.

A persistent wind-induced flow from the Siberian coast across the pole (called Transpolar Drift Stream) to the Fram Strait transports sea ice towards the north coast of Greenland and the Canadian Archipelago and out of the Arctic through the Fram Strait (Kwok and Untersteiner 2011). Every year, approximately $10 \%$ of the sea ice area of the Arctic Basin is exported through the Fram Strait into the North Atlantic Ocean (Smedsrud et al. 2017). Similarly, new ice is formed 
Fig. 1 Liquid FWC in a ORAS4 reanalysis, b ORAP5 reanalysis, c EC-Earth, d EC-Earth-HR, e CMCC-CM2 ORCA1 PI, f CMCCCM2 ORCA025 PI, g CMCC-CM2 ORCA1 PD, h CMCC-CM2 ORCA025 PD, i HadGEM3-GC2 N96, j HadGEM3-GC2 N216 and $\mathbf{k}$ HadGEM3-GC2 N512. The units are meters. The average period is based on the total number of years of every simulation (see Table 1)

in the Arctic Basin and particularly along the Siberian coast. In concordance to these dynamic and thermodynamic processes, the spatial averages of the reanalyses show a spatial gradient in mean sea ice thickness (MSIT) that progressively decreases from the Canadian Archipelago, Canadian Basin and northern Greenland towards the Eurasian part of the Arctic (Fig. 2a, b). In general, the models reproduce the spatial MSIT distribution in the reanalysis with maximum MSIT over the Canadian Archipelago and in the western Arctic. However, the spatial gradient towards thinner ice at the Siberian coast is weaker in most of the models. The ECEarth3.1 model shows a strong MSIT reduction from low to high resolution (Fig. 2c, d). While EC-Earth3.1 shows higher MSIT at low resolution, it shows a strong reduction of MSIT at high resolution, showing almost no ice in the North Atlantic Arctic sector. This low MSIT at high resolution might be due to the strong inflow of Atlantic water into the Arctic.

The pre-industrial CMCC-CM2 (CMCC PI) simulations show generally a much higher MSIT than the reanalysis GLORYS and the present day simulations. While with pre-industrial forcing, high resolution leads to a substantial reduction of MSIT (Fig. 2e, f), this is less clear in the present day (CMCC PD) simulations (Fig. 2g, h). Here, we mainly see a different distribution of the MSIT with thinner ice at both the Siberian coast and the Canadian Archipelago. Both CMCC PD show lower MSIT than both reanalyses.

All HadGEM simulations show also lower MSIT than the GLORYS reanalyses, and we see a systematic decrease of MSIT with increasing atmospheric resolution (Fig. 2i-k).

In order to better understand the changes in FWC and MSIT produced by changes in the model resolution or the forcing, we calculated the difference in FWC and MSIT between low and high resolutions (Figs. 3, 4 respectively) for each model. High resolution simulations were interpolated to the low resolution using cubic interpolation. When low and high ocean resolution simulations (ORCA1 minus ORCA025) are compared, we find that low resolution shows larger FWC over the Central Arctic Ocean and lower FWC over the Kara and Laptev Seas compared with high resolution (Fig. 3a-c), EC-Earth3.1 showing the largest difference. In turn, when lower and higher atmosphere resolutions in the HadGEM simulations are compared, we find that lower resolution shows increased FWC over the Kara and Laptev Seas and decreased FWC over the Beaufort Sea. This result is systematic, since lowest
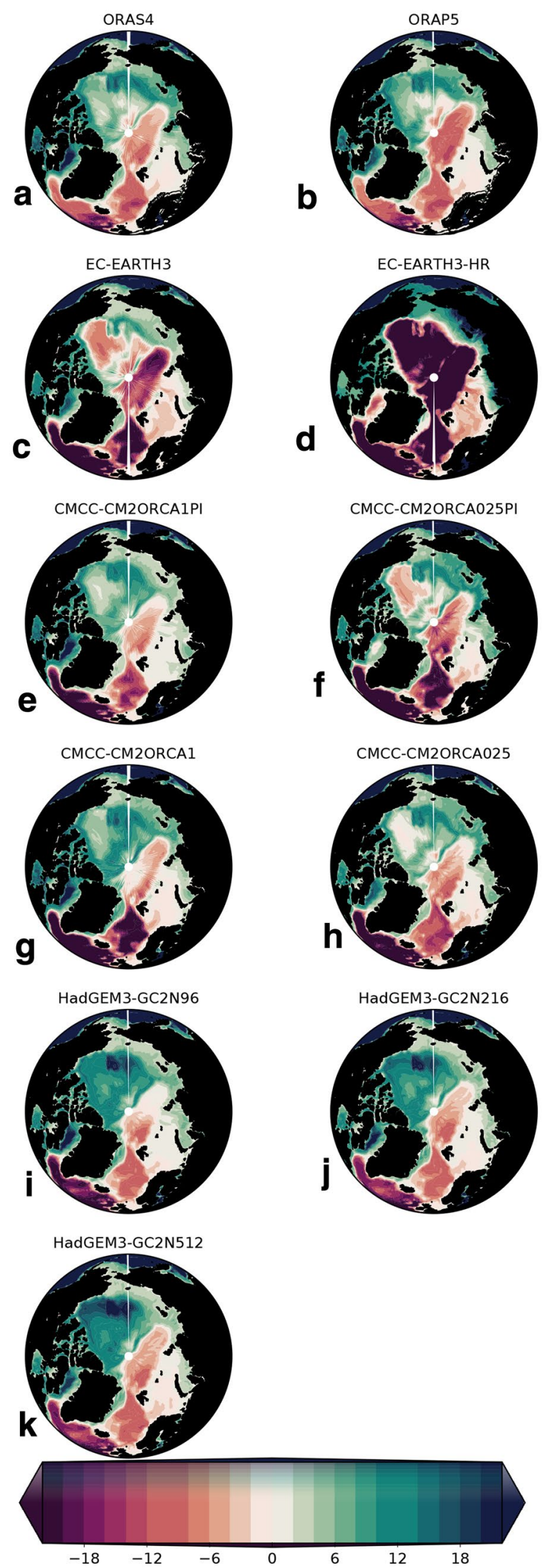
Fig. 2 Mean sea-ice thickness (MSIT) in a GSOP GLORYS2V1 reanalysis, b GLORYS2V4 reanalysis, $\mathbf{c}$ EC-Earth, d EC-Earth-HR, e CMCC-CM2 ORCA1 PI, f CMCC-CM2 ORCA025 PI, g CMCC-CM2 ORCA1 PD, h CMCC-CM2 ORCA025 PD, i HadGEM3GC2 N96, j HadGEM3-GC2 N216 and $\mathbf{k}$ HadGEM3-GC2 $\mathrm{N} 512$. The average period is based on the total number of years of every simulation (see Table 1). The units are meters
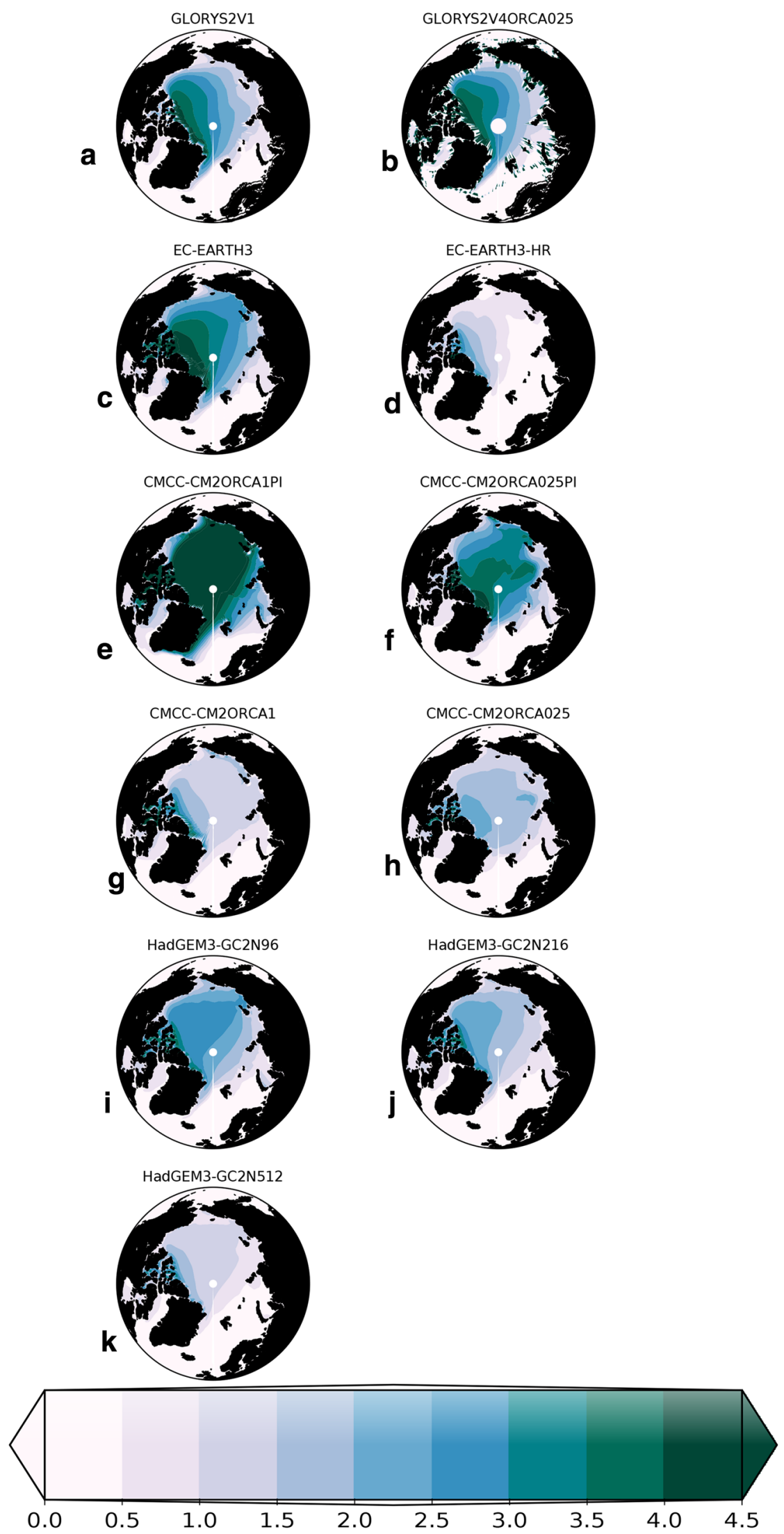

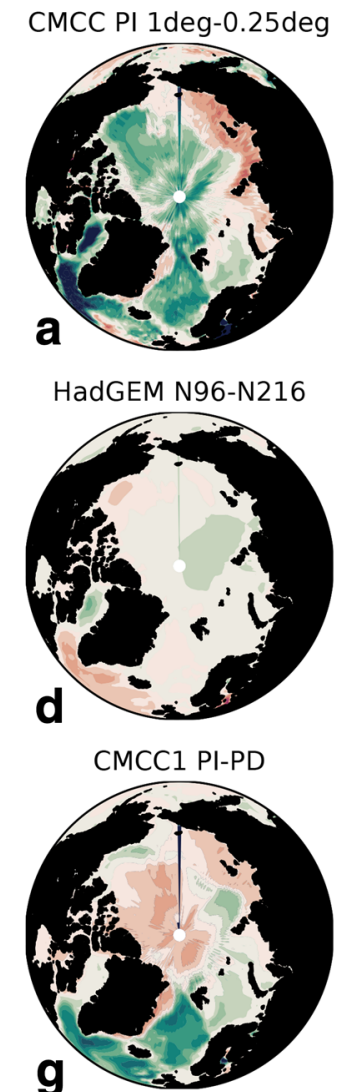
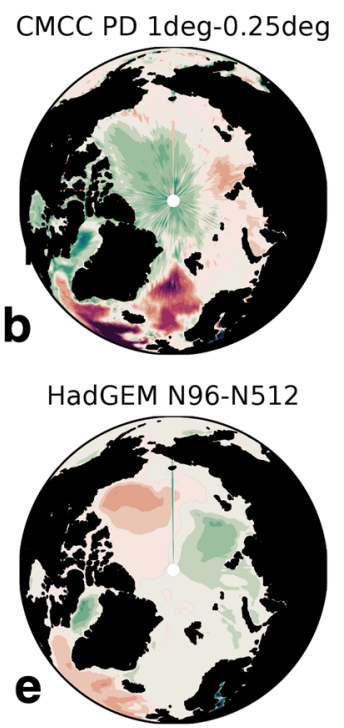

CMCC025 PI-PD

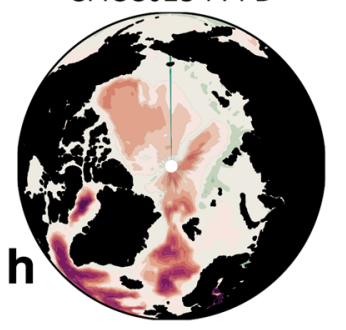

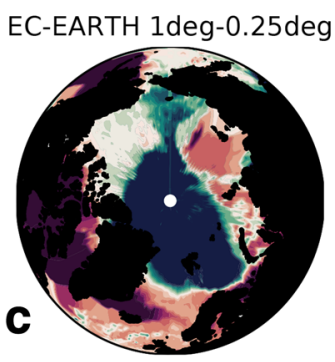

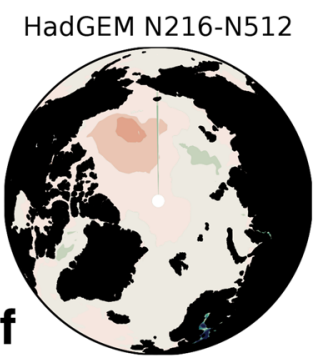

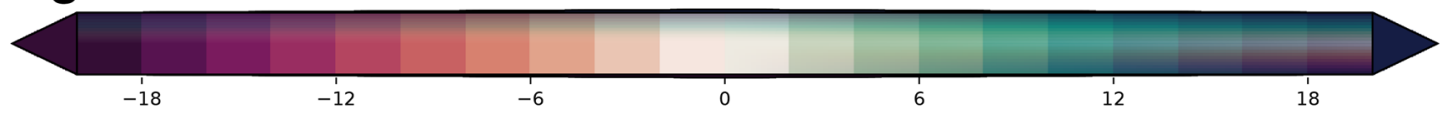

Fig. 3 Difference of liquid FWC between simulations using ORCA1 and simulations using ORCA025 for a CMCC-CM2 PI, b CMCCCM2 PD, c EC-Earth. Difference of liquid FWC between HadGEM simulations using different atmospheric resolutions: d N96 minus N216, e N96 minus N512 and f N216 minus N512. Difference of liq- uid FWC between CMCC simulations using different forcings (present day or pre-industrial) using the same $\mathbf{g}$ ORCA1 and $\mathbf{h}$ ORCA025 grid resolutions. The average period is based on the total number of years of every simulation (see Table 1). The units are meters and highest resolution show the largest FWC difference (Fig. 3d-f). When same resolution pre-industrial and present day forced CMCC simulations are compared, we find lower FWC in the entire Arctic ocean in the pre-industrial simulations (Fig. 3g, h).

Assessing the impact of ocean resolution, we found that low resolution shows higher MSIT than high resolution in CMCC-PI and EC-Earth (Fig. 4a, c), while CMCC-PD shows lower MSIT with lower ocean resolution than with high resolution (Fig. 4b). For EC-Earth3.1, the MSIT reduction might be a combined effect of high atmospheric and oceanic resolutions. The higher MSIT and FWC in CMCCPI and EC-Earth3.1 is apparently due to a net positive inflow of freshwater into the Arctic, which will be further discussed in this section. The lower MSIT along the Arctic ocean in the CMCC-PD at low resolution might be due to a stronger ice response to temperature at lower resolution. It is worth noting that the changes in MSIT due to resolution for CMCC-PD are relatively small compared to CMCC-PI and EC-Earth.

Regarding the impact of changes in atmospheric resolution, as for FWC, systematic change of MSIT with higher atmospheric resolution, showing higher MSIT with lower resolution is found (Fig. 4d-f). Higher MSIT in the lower resolution might lead to a slower ocean circulation in the Beaufort Sea, since thicker ice over the Beaufort Sea, would lead into higher ice strength, which has been shown to decrease the ice speed, hindering the transmission of momentum from the atmosphere into the ocean (Rampal et al. 2011; Olason and Notz 2014; Docquier et al. 2017), which in turn weakens the Ekman convergence, and thus the inflow of freshwater from the Bering Strait into the Beaufort Sea. This contributes to lower FWC in Beaufort Sea at lower atmosphere resolution (Fig. 3d-f). In the same way at low resolution and in line with Roy et al. (2015), the winds acting in the Transpolar drift, might have less contact with the 

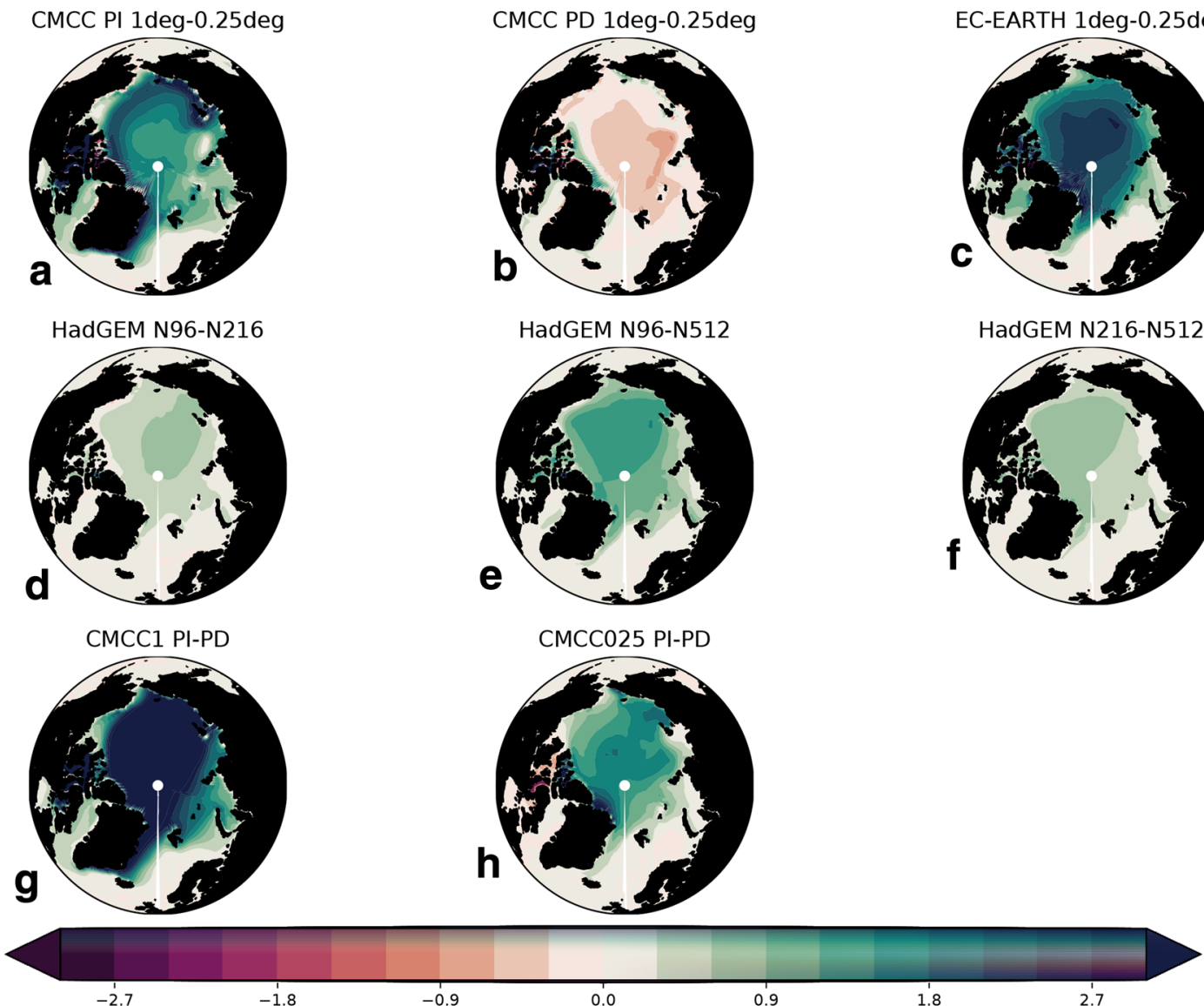

Fig. 4 Difference of mean sea-ice thickness (MSIT) between simulations using ORCA1 and simulations using ORCA025, for a EC-Earth, b CMCC-CM2 PI, c CMCC-CM2 PD. Difference of MSIT between HadGEM simulations using different atmospheric resolutions: d N96 minus N216, e N96 minus N512 and f N216 minus N512. Difference

liquid water on ice-covered Laptev and Kara Seas, decreasing the freshwater transport from the Laptev and Karas seas, and therefore increasing the amount of FWC over this region of the Arctic ocean.

When same resolution pre-industrial and present day forced simulations are compared, we find that MSIT reduction from pre-industrial to present-day run in CMCC is enhanced at low resolution (Fig. 4g, h). Therefore the high MSIT in pre-industrial forced simulations explains and compensates the low liquid FWC (Fig. 3g, h).

To summarize this sub-section, we have found systematic lower freshwater volume with increased ocean and atmospheric resolutions. Although we use models with the same ocean component (NEMO model), the atmospheric components are different and use different parameterizations, which would impact the ice directly, and consequently the freshwater volume. According to Hodson et al. (2013), the majority of Arctic ice-volume and freshwater uncertainties are related to sub-gridscale of MSIT between CMCC simulations using different forcings (present day or pre-industrial) using the same $\mathbf{g}$ ORCA1 and $\mathbf{h}$ ORCA025 grid resolution. The average period is based on the total number of years of every simulation (see Table 1). The units are meters

parameterizations and model structure variations rather than intrinsic internal variability. Therefore, for this study, the different intensities we obtained in the comparison of simulations at different model resolution could arise from different radiation scheme, and ultimately different temperatures in the atmosphere.

Parameter uncertainty seems to play an important role in the spread of variables. Small changes in the radiation scheme, the convection scheme or any other atmospheric or ocean parameterization, can derive in significant changes in the Arctic climate. For example Roy et al. (2015) showed how different atmosphere-ice-ocean surface layer treatments impact the ice volume, freshwater volume and freshwater exports from the Arctic. Structural uncertainty dominates the transports i.e. the large scale circulation, which affects the Arctic key variables (Hodson et al. 2013), however a deeper analysis of sources of uncertainty besides model resolution is out of the scope of this paper. From our study we can remark that resolution has an impact on the spread of 
variables, however parameterization changes matter, particularly when comparing results from different models.

\subsection{Freshwater transport}

In the following sub-section we focus on the freshwater and ice transport from the Arctic. When we analyze the Arctic's liquid freshwater mean inflow and outflow and its variability (Fig. 5; Table 2), we observe that for ORAS4 the largest export of liquid freshwater occurs via the Baffin Bay with a mean outflow of $2280 \mathrm{~km}^{3}$ year $^{-1}$ through North Baffin, comparable with observations $\left(3200 \pm 320 \mathrm{~km}^{3} \mathrm{year}^{-1}\right.$ according to Serreze et al. 2006). For ORAP5, in turn, the outflow across North Baffin is of about $800 \mathrm{~km}^{3}$ year ${ }^{-1}$ which is the second highest export after the Fram strait. We find that all models show a larger agreement with ORAP5 reanalysis on freshwater export across North Baffin Bay (with less than $1550 \mathrm{~km}^{3}$ year $^{-1}$ ). We find that low ocean resolution simulations show higher freshwater export across North Baffin Bay than the high resolution simulations. Models show liquid freshwater exports through Fram Strait similar to observations $\left(2700 \pm 530 \mathrm{~km}^{3} \mathrm{year}^{-1}\right)$, and therefore higher exports than ORAS4 $\left(\sim 1030 \mathrm{~km}^{3} \mathrm{year}^{-1}\right)$ and ORAP5 $\left(\sim 1465 \mathrm{~km}^{3}\right.$ year $\left.^{-1}\right)$, which underestimate the observations. Particularly CMCC-CM2 and HadGEM show the largest freshwater export across Fram Strait $\left(>2200 \mathrm{~km}^{3}\right.$ year $\left.{ }^{-1}\right)$, and therefore the best agreement with observations. Freshwater export across the Barents Sea is small $\left(90 \pm 90 \mathrm{~km}^{3}\right.$ year $^{-1}$ from observations) and there is a spread in simulated freshwater export across models, from about $-1450 \mathrm{~km}^{3}$ year $^{-1}$ in EC-Earth to around $600 \mathrm{~km}^{3}$ year $^{-1}$ in CMCC-ORCA1-PI. Consistent with previous works, we find that the largest liquid freshwater inflow occurs through the Bering Strait supplying around $2840 \mathrm{~km}^{3}$ year $^{-1}$ in ORAS4 and ORAP5, quite similar to observation estimates $\left(2400 \pm 300 \mathrm{~km}^{3}\right.$ year $\left.^{-1}\right)$. Coarse ocean resolution simulations tend to show larger freshwater inflow across Bering Strait than high ocean resolution models, which causes a positive total net inflow of liquid freshwater into the Arctic (red line is always positive in Fig. 5, see Table 2) in EC-Earth3.1 and CMCC-PI. On the other hand, increased atmospheric resolution tends to increase the modelled freshwater export from the Arctic (Fig. 5i-k; Table 2).

Consistently with previous studies (e.g. Vinje et al. 1998; Vinje 2001; Aagaard and Carmack 1989; Schmith and Hansen 2003), in GLORYS2V1 and GLORYS2V4 the largest sea ice exports take place through Fram Strait and amount to $1860 \mathrm{~km}^{3}$ year $^{-1}$ in average (Fig. 6a, b), which is slightly lower than observation estimates (from 2400 to $3200 \mathrm{~km}^{3}$ year $^{-1}$ ). The Fram Strait is properly reproduced by all models as the main gateway with the largest Arctic ice exports (see Table 3 ). The CMCC-PI ORCA1 model shows the largest ice export with $4720 \pm 1580 \mathrm{~km}^{3}$ year $^{-1}$ (Fig. 6e) and high resolution EC-Earth3.1 the smallest with ice export in average around $267 \mathrm{~km}^{3}$ year $^{-1}$ (Fig. 6d). Low ocean resolution simulations show larger ice export across Fram Strait than high resolution simulations (Fig. 6c-h) although the difference is less pronounced in the CMCC-PD simulation (Table 3). Consistent with MSIT (Fig. 3a-c), models that exhibit higher MSIT over the Arctic at low resolution, have larger ice export from the Arctic.

Mean sea ice thickness decreases with increased atmospheric resolution in the HadGEM model (Fig. 4d-f), the ice transport across Fram Strait is also sensitive to changes in atmospheric resolution, and shows smaller values with increased resolution (Fig. 6i-k; Table 3). Higher roughness length at higher atmospheric resolution, due to better representation of the ice surface, increases the momentum transfer from the sea ice to the ocean slowing down the sea ice drift in the Beaufort Gyre. According to Roy et al. (2015), the slower drift reduces sea ice convergence into the center of the Beaufort Gyre, thereby increasing the concentration around the margins of the Beaufort Gyre. The reduction in lead fraction reduces the sea ice growth. This results in a net decrease in the Arctic sea ice volume in higher atmospheric resolutions.

The amount of ice export is comparable to the liquid freshwater export; however the ice export depends more on atmospheric dynamics due to its confinement to the sea surface. Ice motion is largely wind driven, although it is also influenced by ocean currents and ice internal stress, and the amount of ice transport from the Arctic across the Fram Strait has been found to be highly related with the SLP gradient across the Fram Strait. According to Kwok and Rothrock (1999), the SLP gradient explains around $80 \%$ of the variance of the winter ice area flux across Fram Strait. Therefore - in order to analyse differences in the representation of the relation between the SLP gradient and the Fram Strait ice transport across simulations, we calculated correlations between ice transport across the Fram Strait and SLP in every grid point of the northern Hemisphere (Fig. 7; Table 4). The spatial correlation pattern between GLORYS2v1 reanalysis ice transport time series and ERAInterim SLP, show negative correlation in the Eurasian Arctic sector. The most intense negative correlation $(\mathrm{r}<-0.8)$ is located over Svalbard and the Barents Sea (Fig. 7a). The correlation weakens towards the west across the Fram Strait. Dynamically this implies that a negative anomaly of SLP gradient over the Barents Sea would enhance the southward wind component across the Fram Strait, which as a consequence would increase the ice transport towards the south.

When comparing the low versus high ocean resolution simulations with reanalysis, we find that the low resolution simulations tend to reproduce the extension of the negative correlation over the Barents Sea and the eastern Arctic slightly better than high ocean resolution simulations 
Fig. 5 Liquid freshwater transport towards the Arctic in a ORAS4 reanalysis, b ORAP5 reanalysis, $\mathbf{c}$ EC-Earth, d EC-Earth-HR, e CMCC-CM2 ORCA1 PI, f CMCC-CM2 ORCA025 PI, g CMCC-CM2 ORCA1 PD, h CMCC-CM2 ORCA025 PD, i HadGEM3GC2 N96, j HadGEM3-GC2 N216 and $\mathbf{k}$ HadGEM3-GC2 N512. The units are $\mathrm{km}^{3}$ year ${ }^{-1}$. ORAS4 and ORAP5 timeseries include the periods 1958-2012 and 1979-2012, respectively. Periods for models can be found in Table 1. Negative numbers mean freshwater export from the Arctic
Fresh water transport into the Arctic
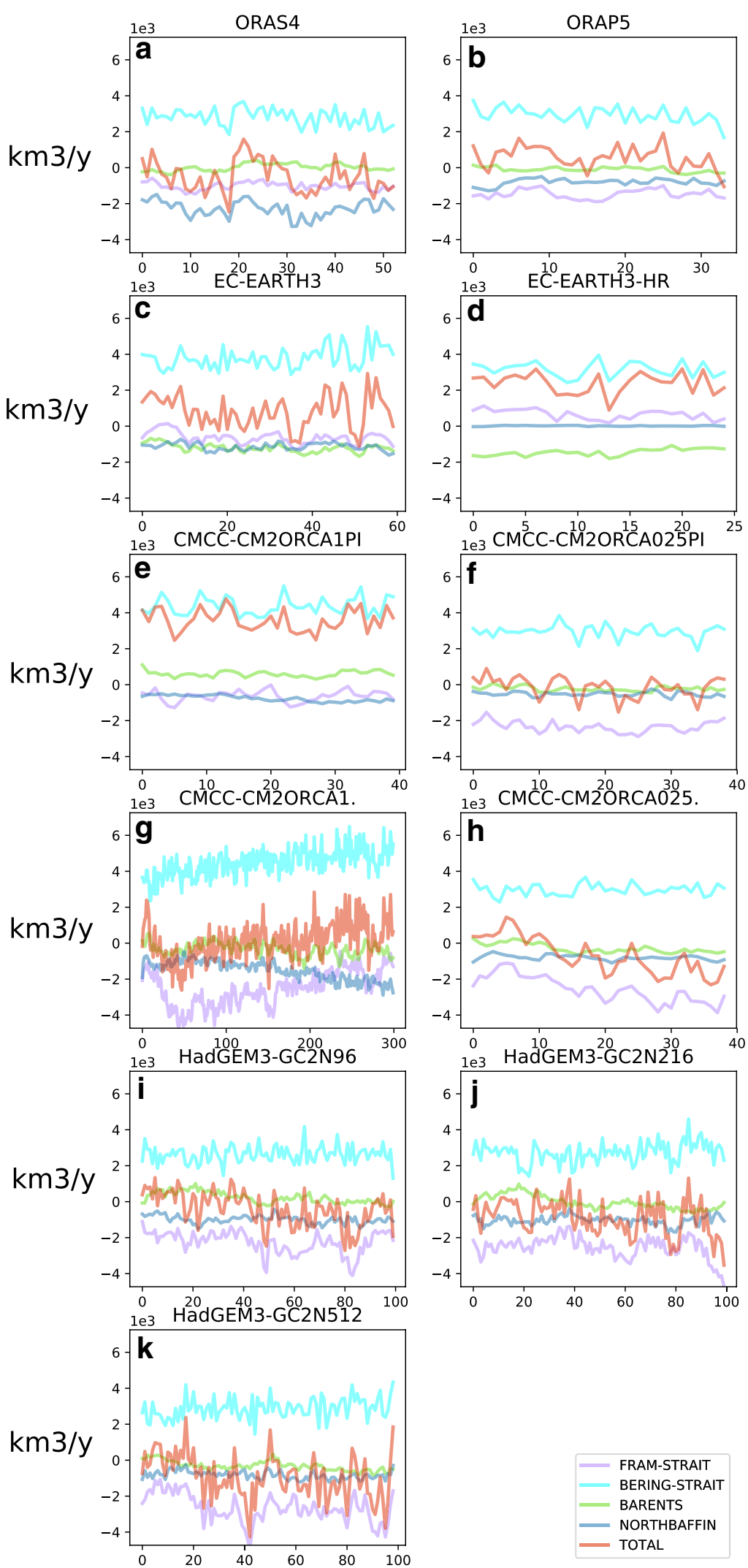
Table 2 Liquid freshwater transport towards the Arctic $\left(\mathrm{km}^{3}\right.$ year $\left.^{-1}\right)$

\begin{tabular}{lrlrrr}
\hline Model & Fram Strait & Bering Strait & Barents & \multicolumn{1}{c}{ North Baffin Bay } & \multicolumn{1}{c}{ Total } \\
\hline ORAS4 & -1029.86 & 2808.73 & 16.41 & -2282.84 & -487.56 \\
ORAP5 & -1463.97 & 2940.99 & -103.90 & -804.73 & 568.38 \\
EC-EARTH3.1 & -641.04 & 3802.31 & -1208.90 & -1138.04 & 814.33 \\
EC-EARTH3.1-HR & 653.98 & 3157.80 & -1448.66 & 14.87 & 2377.99 \\
CMCC-CM2 ORCA1 PI & -630.80 & 4371.25 & 601.83 & -763.96 & 3578.32 \\
CMCC-CM2 ORCA025 PI & -2340.45 & 2963.74 & -233.16 & -524.44 & -134.31 \\
CMCC-CM2 ORCA1 PD & -2539.21 & 4465.46 & -344.30 & -1503.14 & 78.80 \\
CMCC-CM2 ORCA025 PD & -2563.70 & 2976.46 & -290.17 & -802.01 & -679.42 \\
HadGEM3-GC2 N96 & -2262.56 & 2632.29 & 226.79 & -992.28 & -395.77 \\
HadGEM3-GC2 N216 & -2537.00 & 2721.74 & -29.35 & -1034.82 & -879.42 \\
HadGEM3-GC2 N512 & -2654.69 & 2883.45 & -318.17 & -831.76 & -921.17 \\
\hline
\end{tabular}

Negative number means liquid freshwater export from the Arctic. The averages were calculated for the entire number of years displayed in Table 1
(Fig. 7b-g). High ocean resolution simulations show a smaller region of strong negative correlation east of Svalbard with less extension towards the eastern Arctic Ocean. However all of them show a zonal correlation gradient across the Fram Strait.

When comparing the correlation patterns at different atmospheric resolutions in HadGEM, we find that although all simulations show negative correlations over the eastern Arctic, the correlation intensities are lower than in the reanalyses (Fig. $7 \mathrm{~h}-\mathrm{j}$ ). We also observe that the increase in atmospheric resolution does not show a systematic impact on the intensity of the correlations since the intermediate resolution shows the most intense correlation patterns (Fig. 7i) and more similar spatial pattern to the reanalysis, compared to lower (Fig. 7h) and higher resolution (Fig. 7j) simulations. Despite the smaller negative correlation east of Svalbard in HadGEM, we still find that the SLP-gradient across Fram Strait plays a governing role for the ice export. However, in this case, the SLP gradient does also depend on high pressure anomalies over Greenland as much as on low pressure over the Barents Sea area. Table 4 summarizes these results with correlation of ice export from the Arctic across the Fram Strait and the SLP gradient across the Atlantic Sector of the Arctic Ocean.

For the ice transport into the Arctic across the Bering Strait, all models show positive correlation with SLP over the Eastern Siberia and Laptev Seas and negative correlation over Alaska and the North Pacific, reaching the Bering Sea (not shown). Therefore an intensified Aleutian Low pressure would enhance the movement of ice towards the Arctic Ocean. In turn, for the ice export from the Arctic across the Baffin Bay, all models show a strong negative correlation over the Davis Strait and over Greenland (not shown), therefore a low pressure over Greenland and the Davis Strait would promote the northerly winds across the
Baffin Bay enhancing the ice export from the Arctic into the North Atlantic.

\subsection{Impact of ice transport from the Arctic on the North Atlantic convection}

Previous works have shown that convection in the North Atlantic Ocean is highly sensitive to changes in the freshwater balance. An example of this is the Great Salinity Anomaly in the early 1970s. Häkkinen (1999) showed with an idealized study how freshwater pulses in the East Greenland Current cause a reduction in convection in the Labrador Sea. Koenigk et al. (2006) showed that the freshwater exported through the Fram Strait propagates in the East Greenland Current to the south, reaches Labrador Sea in about 1-2 years, and produces a negative salinity anomaly in the Labrador Sea, that strongly reduces the convection. Ensemble simulations by Mikolajewicz et al. (2005) indicated a risk for a decadal-long shutdown of the Labrador Sea convection after huge Fram Strait ice exports.

Here, we investigate only the HadGEM simulations since the other simulations are too short for comparing decadal scale variations. In order to analyse the impact of the atmospheric resolution on the convection in the Labrador Sea and its relationship with freshwater export across the Fram Strait, we compared an index of deep convection in the Labrador Sea (Brodeau and Koenigk 2016) with the previous Fram Strait freshwater export. The convection index is based on March mixed layer depth and takes both vertical and horizontal extensions of the convection areas into account. We used 10-year running mean for both time-series to filter out the high frequencies and to focus on the long term relationship between the freshwater transport across the Fram Strait and the convection in Labrador Sea. We find a systematic behaviour showing a resolution dependence 
Fig. 6 Ice transport towards the Arctic across different straits in a) GLORYS2V1 reanalysis, $\mathbf{b}$ GLORYS2V4, c EC-Earth, d EC-Earth-HR, e CMCC-CM2 ORCA1 PI, f CMCC-CM2 ORCA025 PI, g CMCC-CM2 ORCA1 PD, h CMCC-CM2 ORCA025 PD, i HadGEM3GC2 N96, j HadGEM3-GC2 N216 and $\mathbf{k}$ HadGEM3-GC2 N512. The units are $\mathrm{km}^{3}$ year ${ }^{-1}$. Negative numbers mean ice export from the Arctic. Total values (sum of ice transport across all straits) are shown in red. GLORYS2V1 includes 1993-2009 period and GLORYS2V4 includes the period 1993-2015
Ice transport into the Arctic
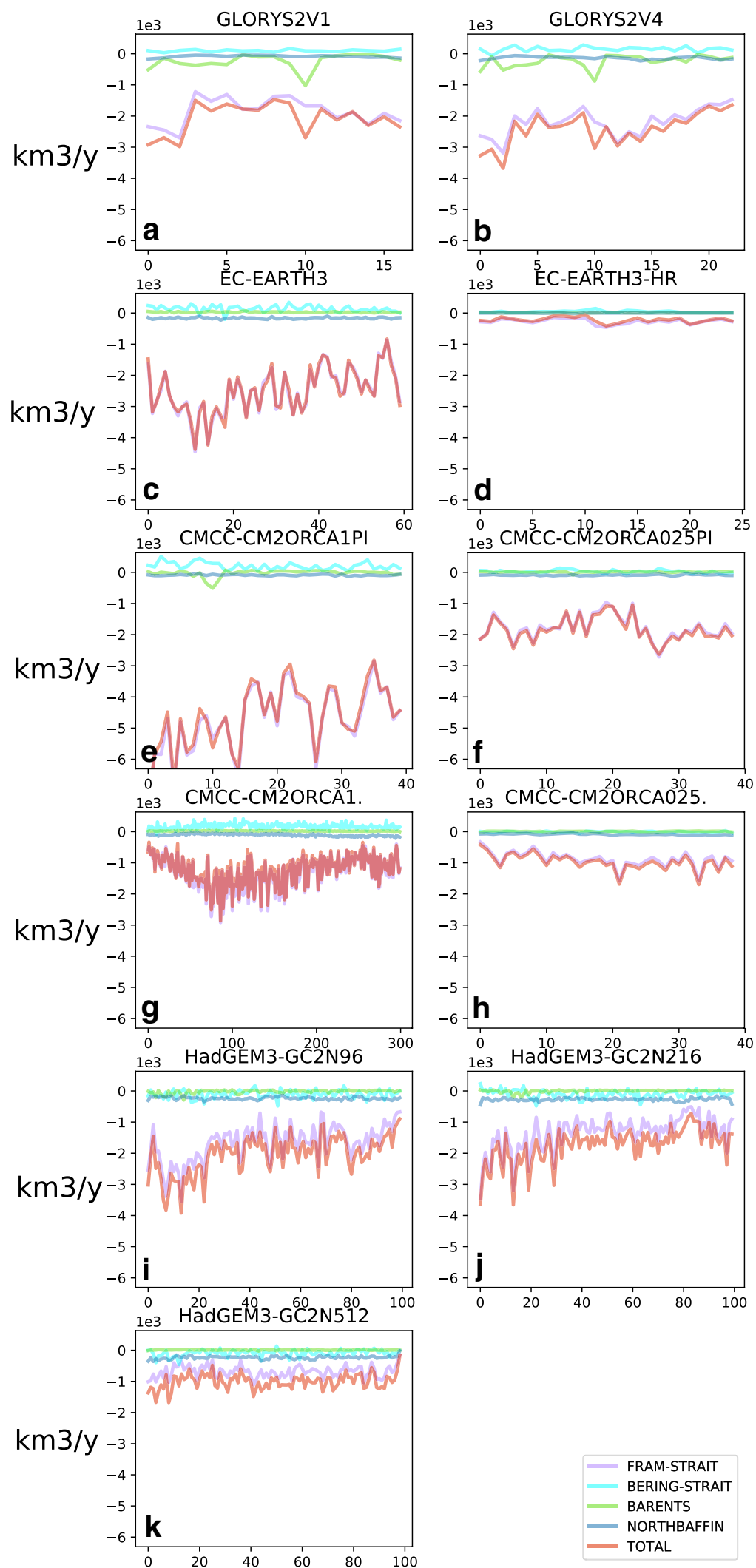
Table 3 Ice transport into the Arctic $\left(\mathrm{km}^{3}\right.$ year $\left.{ }^{-1}\right)$

\begin{tabular}{lrrrrr}
\hline Model & Fram Strait & Bering Strait & Barents & North Baffin Bay & Total \\
\hline GLORYS2V1 & -1848.81 & 98.80 & -240.96 & -86.25 & -2077.22 \\
GLORYS2V4 & -2184.63 & 147.07 & -236.85 & -138.49 & -2412.88 \\
EC-EARTH3.1 & -2515.02 & 136.95 & 28.45 & -160.92 & -2510.54 \\
EC-EARTH3.1-HR & -266.63 & 41.67 & 7.12 & -1.57 & -219.41 \\
CMCC-CM2 ORCA1 PI & -4717.31 & 205.78 & -24.13 & -87.81 & -4623.47 \\
CMCC-CM2 ORCA025 PI & -1780.69 & 26.79 & 8.42 & -88.46 & -1833.95 \\
CMCC-CM2 ORCA1 PD & -1308.54 & 166.65 & 20.60 & -103.71 & -1225.00 \\
CMCC-CM2 ORCA025 PD & -884.18 & -5.86 & 5.30 & -84.11 & -968.86 \\
HadGEM3-GC2 N96 & -1688.38 & -100.93 & -20.94 & -235.10 & -2045.36 \\
HadGEM3-GC2 N216 & -1364.33 & -91.60 & -4.62 & -268.92 & -1729.48 \\
HadGEM3-GC2 N512 & -690.62 & -84.26 & 7.88 & -234.25 & -1000.93 \\
\hline
\end{tabular}

For consistency with freshwater exports, negative number means ice export out of the Arctic. The averages were calculated for the entire number of years displayed in Table 1 of the relationship; the correlations between ice export and convection were for the low resolution $r=0.31$, for the intermediate resolution $r=0.52$, and for the highest resolution $r=0.57$ (Fig. 8) when the ice transport leads the convection with 1 year for all resolutions.

The deep convection is reduced with higher resolution in the HadGEM model (Fig. 9). In general, all three model simulations show higher convection in the Labrador Sea compared to ARGO-mixed layers (Holte et al. 2010) and particularly, the low resolution simulation shows deep convection every year. Thus, the convection is less sensitive to changes in the upper surface density due to freshwater inflow in the low resolution simulation compared to the high resolution simulation. The reason for the lower convection in high resolution is not entirely clear. While the turbulent surface heat fluxes are very similar in all three model setups (not shown) and also liquid and solid freshwater exports through Fram Strait agree well (Figs. 5, 6), the freshwater export through the Davis Strait is slightly larger in the highresolution simulations (Fig. 5) and could be the reason for slightly increased vertical stratification in the Labrador Sea at high resolution.

\section{Conclusions}

Models participating in the H2020 Primavera project were used to analyse the impact of changes in atmospheric and ocean resolutions on the Arctic freshwater budget. We found that low ocean resolution shows larger liquid FWC over the Central Arctic Ocean and lower FWC over the Kara and Laptev Seas compared with high resolution. We did not find a similar systematic behaviour across different models for the MSIT.

In a systematic way, when changing the atmospheric resolution, we found that the lower the resolution the larger the
FWC over the Kara and Laptev Seas and the lower the FWC over the Beaufort Sea. Similarly, a systematic decrease of MSIT with higher resolution is found. The larger presence of ice over the Beaufort Sea in the low resolution reduces the effect of atmospheric anticyclonic wind circulation on the ocean circulation, weakening the Ekman convergence, and therefore the inflow of freshwater from the Bering Strait into the Beaufort Sea, which consequently increases the inflow of freshwater into the Laptev and Kara Seas.

Pre-industrial atmospheric forcing showed less FWC and increased MSIT compared with present day forcing.

Although we have consistency in our results (higher FWC at coarser ocean resolution, higher FWC in the Laptev Sea while lower FWC over the Beaufort sea and higher MSIT in the whole Arctic at coarser atmospheric resolution, higher FWC and lower MSIT in the PD simulations), we can not determine the effect of changes in a particular term in the model parameterization on the variables we analyzed. This leads to a parameter uncertainty within the different results. All of the models used in this study used NEMO as the ocean component, however small changes in a parameterization across models could cause different responses across variables when comparing them in high and low resolutions. In this study we do not focus on the uncertainty coming from model parameterization but we stress that the spread in modelled freshwater volume, sea ice volume and northward ocean heat transport into the Arctic are significant factors in the uncertainty in Arctic climate.

In terms of freshwater transport, most of the models (except EC-Earth and CMCC-CM2 ORCA1 PI) show the highest freshwater export from the Arctic occurring across the Fram strait, with higher exports than the reanalyses. The gateway with the second highest freshwater export from the Arctic across models is Davis strait, showing a slightly increased freshwater export with increased ocean resolution. Coarse ocean resolution models show larger freshwater 

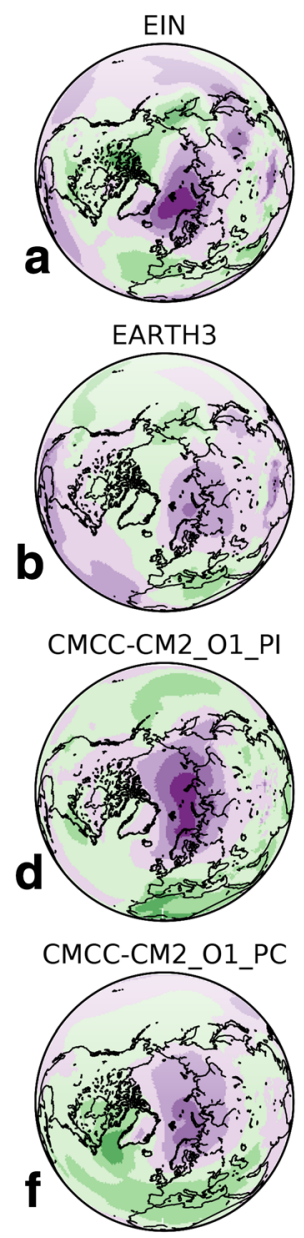

HadGEM-GC2_N960025
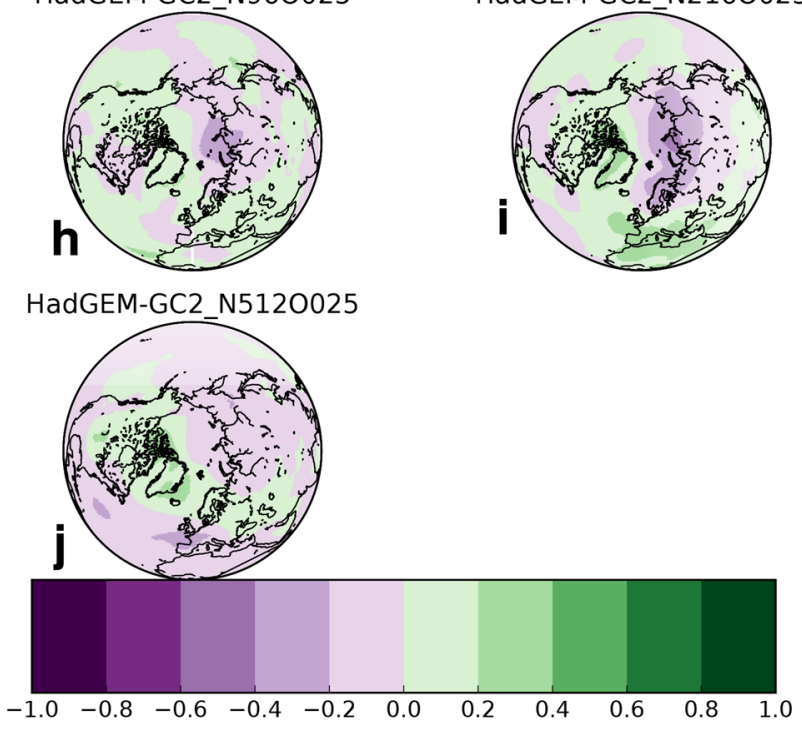

Fig. 7 Correlation of detrended ice export across the Fram strait and SLP for a Era Interim reanalysis (ice export from GLORYS), b EC-Earth, c EC-Earth-HR, d CMCC-CM2 ORCA1 PI, e CMCCCM2 ORCA025 PI, f CMCC-CM2 ORCA1 PD, g CMCC-CM2 ORCA025 PD, h HadGEM3-GC2 N96, i HadGEM3-GC2 N216 and j HadGEM3-GC2 N512
Table 4 Correlation between ice export across Fram Strait and SLP gradient across Atlantic sector of the Arctic Ocean

\begin{tabular}{ll}
\hline Model & Correlation \\
\hline GLORYS-ERA-Interim & 0.71 \\
EC-EARTH3.1 & 0.53 \\
EC-EARTH3.1-HR & 0.61 \\
CMCC-CM2 ORCA1 PI & 0.61 \\
CMCC-CM2 ORCA025 PI & 0.45 \\
CMCC-CM2 ORCA1 PD & 0.63 \\
CMCC-CM2 ORCA025 PD & 0.42 \\
HadGEM3-GC2 N96 & 0.25 \\
HadGEM3-GC2 N216 & 0.47 \\
HadGEM3-GC2 N512 & 0.22 \\
\hline
\end{tabular}

The SLP gradient was calculated with the subtraction of the mean SLP within the areal covered by latitudes between $60^{\circ} \mathrm{N}$ and $80^{\circ} \mathrm{N}$, longitudes between $0^{\circ}$ and $80^{\circ} \mathrm{E}$, and area 2 within latitudes between $60^{\circ} \mathrm{N}$ and $82^{\circ} \mathrm{N}$ and longitudes between $41^{\circ} \mathrm{W}$ and $75^{\circ} \mathrm{W}$

influx towards the Arctic across the Bering Strait, which might be the factor that causes the higher FWC. Changes in atmospheric resolution seem to produce changes in the amounts of freshwater transport from the Arctic, with increased freshwater total export from the Arctic with higher atmospheric resolution. In turn, the connection between the convection in the Labrador Sea and freshwater transport across the Fram Strait seems to be much stronger in high atmospheric resolution. Further research is needed to better understand the strengthening of this linkage with increased atmospheric resolution.

Ice transport is higher at lower resolution ocean models. Ice transport across Fram Strait is also sensitive to changes in atmospheric resolution, and shows smaller values with increased resolution. Ice transport under pre-industrial forcing is, as expected, much higher than under present day forcing due to thicker ice.

All models reproduce the observed dominant effect of the local winds on the Fram Strait ice export. The SLP gradient across the Fram Strait and its linkage to ice export to the North Atlantic, does not seem to be strongly affected by changes in ocean and atmospheric resolutions, however changes in the spatial correlation patterns arise at high ocean resolution, showing smaller areas of strong correlation compared to low resolution, where large correlation areas are related with the ice export to the Atlantic.

In this study, we used a non-coordinated, diverse set of model simulations. The co-ordinated HighResMIP simulations will provide a useful data base for validating the results from this study and extending the analysis on Arctic freshwater and its impact on climate. 

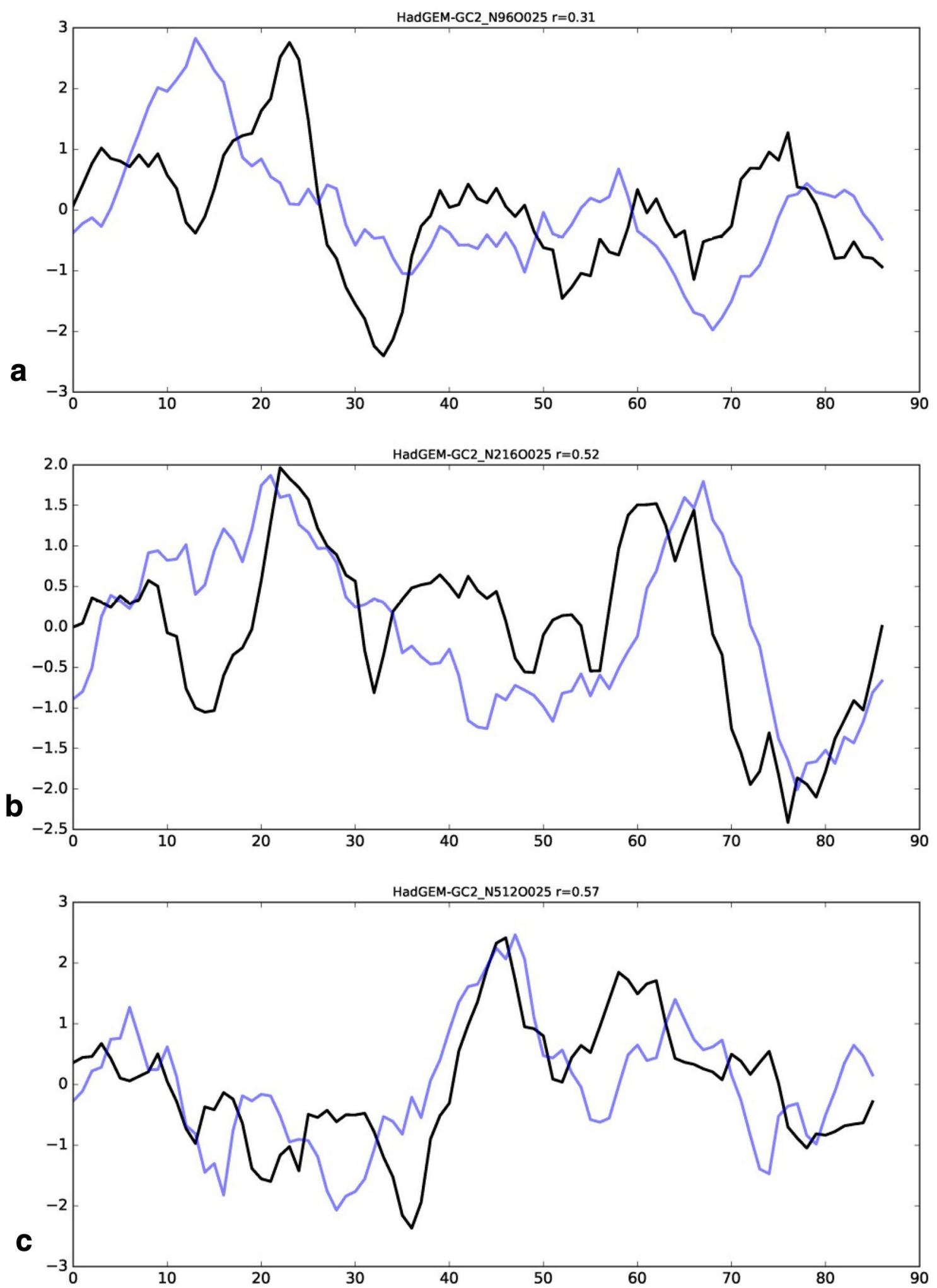

Fig. 8 Standardized timeseries of 10 year running mean ice transport (blue) and convection in the Labrador Sea (black) for a HadGEM3-GC2 N96, b HadGEM3-GC2 N216 and c HadGEM3-GC2 N512 simulations 


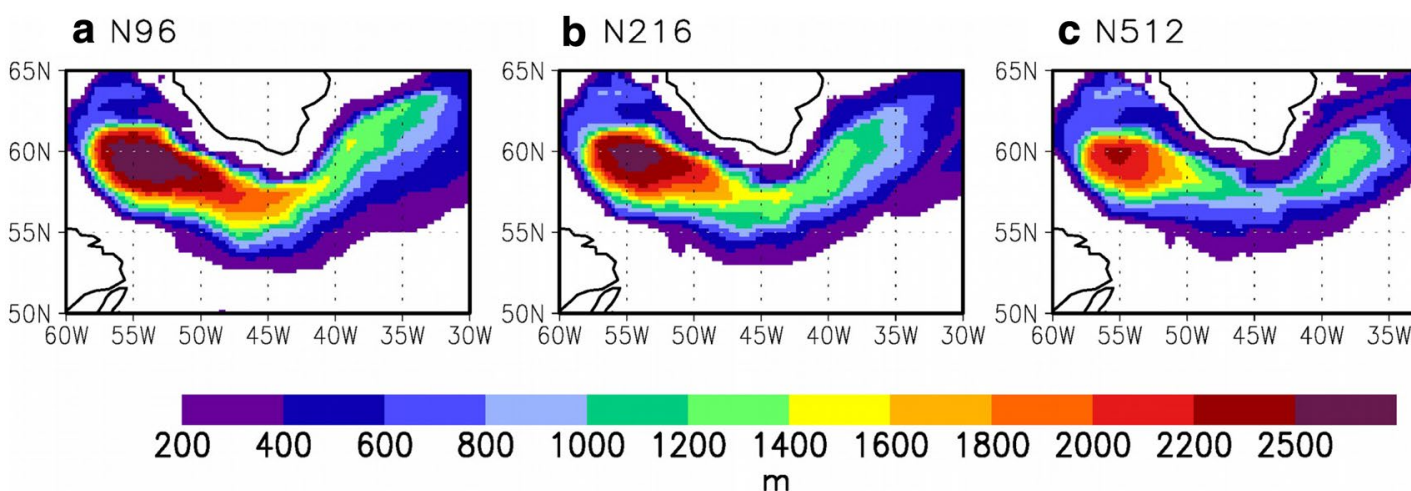

Fig. 9 Mixed layer depth in $\mathrm{m}$ in March, averaged over the 100 year-HadGEM3-GC2 simulations in a low atmospheric resolution, N96, b medium atmospheric resolution, N216, $\mathbf{c}$ high atmospheric resolution, N512

Acknowledgements The PRIMAVERA project is funded by the European Union's Horizon 2020 programme, Grant Agreement no. 641727. Funding is also provided from the JPI-Climate-Belmont Forum project 407, InterDec. Part of this work was carried out using resources provided by the Swedish National Infrastructure for Computing (SNIC) at the National Supercomputer Centre at Linköping University (NSC).

Open Access This article is distributed under the terms of the Creative Commons Attribution 4.0 International License (http://creativeco mmons.org/licenses/by/4.0/), which permits unrestricted use, distribution, and reproduction in any medium, provided you give appropriate credit to the original author(s) and the source, provide a link to the Creative Commons license, and indicate if changes were made.

\section{References}

Aagaard K, Carmack E (1989) The role of sea ice and other freshwater in the Arctic circulation. J Geophys Res 94:14485-14498

Balmaseda MA, Mogensen K, Weaver AT (2013) Evaluation of the ECMWF ocean reanalysis system ORAS4. QJR Meteorol Soc 139:1132-1161. https://doi.org/10.1002/qj.2063

Barnier B, Madec G, Penduff T, Molines JM, Treguier AM, Le Sommer J, Beckmann A, Biastoch A, Böning C, Dengg J, Derval C (2009) Impact of partial steps and momentum advection schemes in a global ocean circulation model at eddy-permitting resolution. Ocean Dyn 59(3):537-537

Berezovskaya S, Yang D, Hinzman L (2005) Long-term annual water balance analysis of the Lena River. Glob Planet Change 48(1-3):84-95

Brauch JP, Gerdes R (2005) Reaction of the northern North Atlantic and Arctic oceans to a sudden change of the NAO. J Geophys Res 110:C11018. https://doi.org/10.1029/2004JC002436

Brodeau L, Koenigk T (2016) Extinction of the northern oceanic deep convection in an ensemble of climate model simulations of the 20th and 21st centuries. Clim Dyn 46(9-10):2863-2882

Craig AP, Vertenstein M, Jacob R (2012) A new flexible coupler for earth system modeling developed for CCSM4 and CESM1. Int J High Perform C 26(1):31-42

Déry SJ, Wood EF (2005) Decreasing river discharge in northern Canada. Geophys Res Lett 32(10):L10401. https://doi. org/10.1029/2005GL022845

Dickson R, Meincke J, Malmberg SA, Lee A (1988) The "Great Salinity Anomaly"' in the northern North Atlantic, 1968-1982. Progr Oceanogr 20:103-151
Docquier D, Massonnet F, Barthélemy A, Tandon NF, Lecomte O, Fichefet T (2017), Relationships between Arctic sea ice drift and strength modelled by NEMO-LIM3. 6. Cryosphere 11:2829-2846

Ferry N, Parent L, Garric G, Barnier B, Jourdain NC (2010) Mercator global Eddy permitting ocean reanalysis GLORYS1V1: description and results. Mercator Ocean Q Newslett 36:15-27

Ferry N, Parent L, Garric G, Bricaud C, Testut CE, Le Galloudec O, Lellouche JM, Drevillon M, Greiner E, Barnier B, Molines JM (2012) GLORYS2V1 global ocean reanalysis of the altimetric era (1992-2009) at mesoscale. Mercator Ocean Q Newslett 44:29-39

Fogli PG, Iovino D (2014) CMCC-CESM-NEMO: toward the new CMCC earth system model. CMCC Research Paper. Dec(248)

Goosse H, Fichefet T (1999), Importance of ice-ocean interactions for the global ocean circulation: a model study, J Geophys Res 104:23337-23355

Haak H, Jungclaus J, Mikolajewicz U, Latif M (2003) Formation and propagation of great salinity anomalies. Geophys Res Lett 30(9):1473. https://doi.org/10.1029/2003GL017065

Haarsma RJ, Roberts MJ, Vidale PL, Senior CA, Bellucci A, Bao Q, Chang P, Corti S, Fuckar NS, Guemas V, Von Hardenberg J (2016) High resolution model intercomparison project (HighResMIP v1. 0) for CMIP6. Geosci Model Dev 9(11):4185

Haine TW, Curry B, Gerdes R, Hansen E, Karcher M, Lee C, Rudels B, Spreen G, de Steur L, Stewart KD, Woodgate R (2015) Arctic freshwater export: Status, mechanisms, and prospects. Glob Planet Change 125:13-35

Häkkinen S (1999) A simulation of thermohaline effects of a great salinity anomaly. J Clim 12(6):1781-1795

Hazeleger W, Severijns C, Semmler T, Ştefănescu S, Yang S, Wang X, Wyser K, Dutra E, Baldasano JM, Bintanja R, Bougeault (2010) EC-Earth: a seamless earth-system prediction approach in action. B Am Meteorol Soc 91(10):1357-1364

Hazeleger W, Wang X, Severijns C, Ştefănescu S, Bintanja R, Sterl A, Wyser K, Semmler T, Yang S, Van den Hurk B, Van Noije T (2012) EC-Earth V2. 2: description and validation of a new seamless earth system prediction model. Clim Dyn 39(11):2611-2629

Hilmer M, Harder M, Lemke P (1998) Sea ice transport: a highly variable link between Arctic and North Atlantic. Geophys Res Lett 25:3359-3362

Hodson DL, Keeley SP, West A, Ridley J, Hawkins E, Hewitt HT (2013) Identifying uncertainties in Arctic climate change projections. Clim Dyn 40(11-12):2849-2865

Holland MM, Bitz CM, Eby M, Weaver AJ (2001) The role of iceocean interactions in the variability of the North Atlantic thermohaline circulation. J Clim 14(5):656-675 
Holte J, Gilson J, Talley L, Roemmich D (2010) Argo mixed layers. Scripps Institution of Oceanography, UCSD. http://mixedlayer .ucsd.edu. Accessed Mar 2018

Hunke EC, Lipscomb WH (2008), CICE: the Los Alamos sea ice model user's manual, version 4, Los Alamos National Laboratory Tech. Rep. LA-CC-06-012

Hurrell JW, Holland MM, Gent PR, Ghan S, Kay JE, Kushner PJ, Lamarque JF, Large WG, Lawrence D, Lindsay K, Lipscomb WH (2013) The community earth system model: a framework for collaborative research. B Am Meteorol Soc 94(9):1339-1360

Ilicak M, Drange H, Wang Q, Gerdes R, Aksenov Y, Bailey D, Bentsen M, Biastoch A, Bozec A, Böning C, Cassou C (2016) An assessment of the Arctic Ocean in a suite of interannual COREII simulations. Part III: hydrography and fluxes. Ocean Model 100:141-161

Jahn A, Aksenov Y, Cuevas BA, Steur L, Häkkinen S, Hansen E, Herbaut C, Houssais MN, Karcher M, Kauker F, Lique C (2012) Arctic Ocean freshwater: How robust are model simulations? J Geophys Res Oceans 117:C8

Jungclaus JH, Haak H, Latif M, Mikolajewicz U (2005) Arctic-North Atlantic interactions and multidecadal variability of the meridional overturning circulation. J Clim 18(19):4013-4031

Koenigk T, Brodeau L (2017) Arctic climate and its interaction with lower latitudes under different levels of anthropogenic warming in a global coupled climate model. Clim Dyn 49(1-2):471-492

Koenigk T, Mikolajewicz U, Haak H, Jungclaus J (2006) Variability of Fram Strait sea ice export: causes, impacts and feedbacks in a coupled climate model. Clim Dyn 26:17-34. https://doi.org/10.1007/ s00382-005-0060-1

Koenigk T, Mikolajewicz U, Haak H, Jungclaus J (2007) Arctic freshwater export in the 20th and 21st centuries. J Geophys Res 112:G04S41. https://doi.org/10.1029/2006JG000274

Kwok R, Rothrock DA (1999) Variability of Fram Strait ice flux and North Atlantic Oscillation. J Geophys Res 104:5177-5189

Kwok R, Untersteiner N (2011) The thinning of Arctic sea ice. Phys Today 64(4):36-41

Large W, Yeager S (2004) Diurnal to decadal global forcing for ocean and sea-ice models: the data sets and climatologies, Technical Report TN-460 + STR, NCAR

Lawrence DM, Oleson KW, Flanner MG, Thornton PE, Swenson SC, Lawrence PJ, Zeng X, Yang ZL, Levis S, Sakaguchi K, Bonan GB (2011) Parameterization improvements and functional and structural advances in version 4 of the Community Land Model. J Adv Model Earth Syst 3(1):M03001. https://doi.org/10.1029/2011M S000045

Madec G (2008) NEMO reference manual, ocean dynamics component: NEMO-OPA. Preliminary version. Note du Pole de modelisation 27. Institut Pierre-Simon Laplace, Paris

Madec G, The NEMO Team (2012) NEMO ocean engine. Note du Pole de modélisation de l'Institut Pierre-Simon Laplace, France, No 27 ISSN No 1288-1619

McClelland JW, Déry SJ, Peterson BJ, Holmes RM, Wood EF (2006) A pan-arctic evaluation of changes in river discharge during the latter half of the 20th century. Geophys Res Lett 33(6):L06715. https://doi.org/10.1029/2006GL025753

Mikolajewicz U, Sein DV, Jacob D, Königk T, Podzun R, Semmler $\mathrm{T}$ (2005) Simulating Arctic sea ice variability with a coupled regional atmosphere-ocean-sea ice model. Meteorol Z 14(6):793-800

Mogensen K, Balmaseda MA, Weaver AT (2012) The NEMOVAR ocean data assimilation system as implemented in the ECMWF ocean analysis for System 4. Tech. Memo. 668. ECMWF: Reading, UK
Olason E, Notz D (2014) Drivers of variability in Arctic seaice drift speed. J Geophys Res 119:5755-5775. https://doi. org/10.1002/2014JC009897

Peterson BJ, Holmes RM, McClelland JW, Vörösmarty CJ, Lammers RB, Shiklomanov AI, Shiklomanov IA, Rahmstorf S (2002) Increasing river discharge to the Arctic Ocean. Science 298(5601):2171-2173

Rampal P, Weiss J, Dubois C, Campin JM (2011) IPCC climate models do not capture Arctic sea ice drift acceleration: Consequences in terms of projected sea ice thinning and decline. J Geophys Res 116:C00D07. https://doi.org/10.1029/2011JC007110, 2011

Rennermalm AK, Wood EF, Weaver AJ, Eby M, Derý SJ (2007), Relative sensitivity of the Atlantic meridional overturning circulation to river discharge into Hudson Bay and the Arctic Ocean. J Geophys Res. https://doi.org/10.1029/2006JG000330

Roy F, Chevallier M, Smith GC, Dupont F, Garric G, Lemieux JF, Lu Y, Davidson F (2015) Arctic sea ice and freshwater sensitivity to the treatment of the atmosphere-ice-ocean surface layer. J Geophys Res 120(6):4392-4417

Schmith T, Hansen C (2003) Fram Strait ice export during 19th and 20th centuries: evidence for multidecadal variability. J Clim 16:2782-2791

Serreze MC, Barrett AP, Slater AG, Woodgate RA, Aagaard K, Lammers RB, Steele M, Moritz R, Meredith M, Lee CM (2006) The large-scale freshwater cycle of the Arctic. J Geophys Res 111:C11010. https://doi.org/10.1029/2005JC003424

Smedsrud LH, Halvorsen MH, Stroeve JC, Zhang R, Kloster K (2017) Fram Strait sea ice export variability and September Arctic sea ice extent over the last 80 years. Cryosphere 11(1):65

Sterl A, Bintanja R, Brodeau L, Gleeson E, Koenigk T, Schmith T, Semmler T, Severijns C, Wyser K, Yang S (2012) A look at the ocean in the EC-Earth climate model. Clim Dyn 39(11):2631-2657

Vancoppenolle M, Bouillon S, Fichefet T, Goose H, Lecomte O, Morales Maqueda MA, Madec G (2012) LIM The Louvain-laNouve sea Ice Model. Note du Pole de modélisation, Institute Pierre-Simon Laplace (IPSL), France

Vinje T (2001) Fram Strait ice effluxes and atmospheric circulation 1950-2000. J Clim 14:3508-3517

Vinje T, Nordlund N, Kvambeck A (1998) Monitoring ice thickness in Fram Strait. J Geophys Res 103:10437-410449

Wang Q, Wekerle C, Danilov S, Wang X, Jung T (2017) A 4.5 km resolution Arctic Ocean simulation with the global multi-resolution model FESOM1. 4. Geosci Model Dev Discuss. https://doi. org/10.5194/gmd-2017-136

Williams KD, Harris CM, Bodas-Salcedo A, Camp J, Comer RE, Copsey D, Fereday D, Graham T, Hill R, Hinton T, Hyder P (2015) The met office global coupled model 2.0 (GC2) configuration. Geosci Model Dev 8(5):1509

Woodgate RA, Aagaard K, Weingartner TJ (2006) Interannual changes in the Bering Strait fluxes of volume, heat and freshwater between 1991 and 2004. Geophys Res Lett. https://doi.org/10.1029/2006G L026931

Zuo H, Balmaseda MA, Mogensen K (2015) The ECMWFMyOcean2 eddy-permitting ocean and sea-ice reanalysis ORAP5. Part 1: implementation, ECMWF technical memorandum 736

Publisher's Note Springer Nature remains neutral with regard to jurisdictional claims in published maps and institutional affiliations. 